\title{
Recordando en azul: Brindis por la Memoria de Ricardo Llopesa
}

\section{Remembering in blue: Toast to the memory of Ricardo Llopesa \\ Lembrando em azul: brinde à memória de Ricardo Llopesa}

\author{
José Siles González
}

\section{Catedrático de la Facultad de Ciencias de la Salud de la Universidad de Alicante}

Cómo citar este obituario en edición digital: Siles-González, J. (2018). Recordando en azul: Brindis por la Memoria de Ricardo Llopesa. Cultura de los Cuidados (Edición digital), 22(52). Recuperado de $<$ http://dx.doi.org/10.14198/cuid.2018.52.25>

Correspondencia: Departamento de enfermería. Universidad de Alicante. 03080-Alicante (España)

Correo electrónico: jose.siles@ua.es

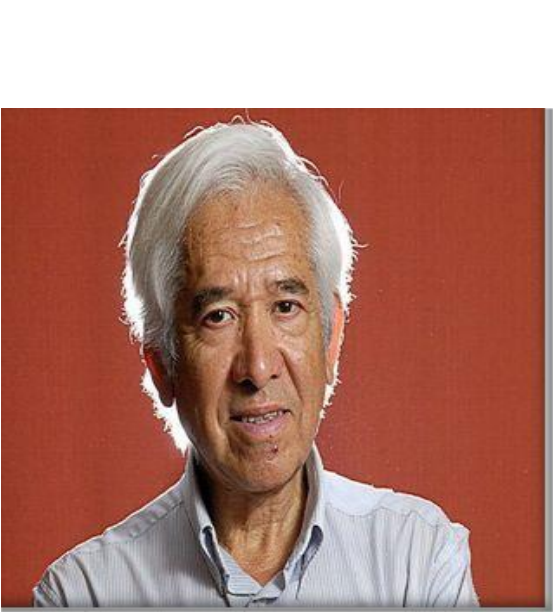

FUENTE: Revista literaria Letralia.

Recuperado de $<$ https://letralia.com/noticias/2018 /07/28/murio-ricardo-llopesa/>

\section{ABSTRACT}

This obituary describes Ricardo Llopesa's career as a writer, poet and literary critic and recalls some of the experiences shared with the author with a Nicaraguan poet.

Keywords: Ricardo Llopesa, Rubén Darío, Academy of the Nicaraguan language.

\section{RESUMO}

Este obituário descreve a carreira de Ricardo Llopesa como escritor, poeta e crítico literário e recorda algumas das experiências compartilhadas com o autor com um poeta Nicaragüano.

Palavras-chave: Ricardo Llopesa, Rubén Darío, Academia da língua Nicaragüana.

\section{RESUMEN}

En este obituario se describe la trayectoria de Ricardo Llopesa como escritor, poeta y crítico literario y se recuerdan algunas de las vivencias compartidas con el autor con poeta nicaragüense.

Palabras clave: Ricardo Llopesa, Rubén Darío, Academia de la Lengua Nicaragüense.

Ricardo Llopesa fue muchas cosas. Vino a Europa a mediados de los sesenta a estudiar la carrera de medicina en Madrid, 
pero las amistades que se encontró en el transcurso inicial de sus viajes por París, Grenoble o Lille, y, sobre todo, la seducción embriagadora que la diosa literatura provocó en él, lograron transformar su objetivo inicial en un bonito recuerdo que poblaba su memoria y que Ricardo desempolvaba sólo cuando en alguna ocasión, por alguna circunstancia que lo requería, se refería a los orígenes de su viaje al viejo continente. Tuvo ocasión de charlar con Sartre y cultivar amistades como las de Pablo Neruda y Miguel Ángel Asturias. Circula una leyenda por ahí que identifica el hecho determinante de su dedicación a la literatura por culpa del hijo del maestro de Rubén Darío, quien a la sazón ejercía de cónsul en París.

De esta manera, Ricardo Llopesa acabó preso de su amor por la literatura y ejerció de poeta, crítico literario y narrador. Se especializó, como no podía ser de otra forma, en el movimiento modernista $y$ dedico gran parte de su tiempo y esfuerzo al estudio de su compatriota Rubén Darío. Escribió varios libros recogiendo aspectos poco conocidos o inéditos del gran poeta del modernismo: Poesías desconocidas completas, Poesías inéditas, Prosas profanas, Los raros, Rubén Darío y el 98, etcétera. Una de sus últimas obras: Modernidad, Modernismo y Antimodernismo está dedicada a Ortega y al Quijote. En definitiva, su trabajo dio como fruto más de veinte estudios críticos de Rubén Darío que fueron editados por prestigiosas editoriales como Espasa Calpe, Visor, Austral o Planeta.

Pero además de su labor filológica y de crítica literaria, Ricardo Llopesa se dedicó a otros menesteres: editor, divulgador $\mathrm{y}$ dinamizador literario. Organizó presentaciones, lecturas poéticas, estrechó lazos entre las diferentes tendencias remarcadas por grupos nacionales e internacionales de poetas. En esta línea hay que interpretar que a mediados de los noventa fundara la Asociación y Editorial Instituto de Estudios Modernistas, la Asociación Valenciana de Escritores y Críticos Literarios (de la que fue presidente) y además tuviera tiempo para crear la revista Ojobuey. Además de todo ello, Ricardo Llopesa fue desde 1997 miembro de la Academia Nicaragüense de la Lengua.

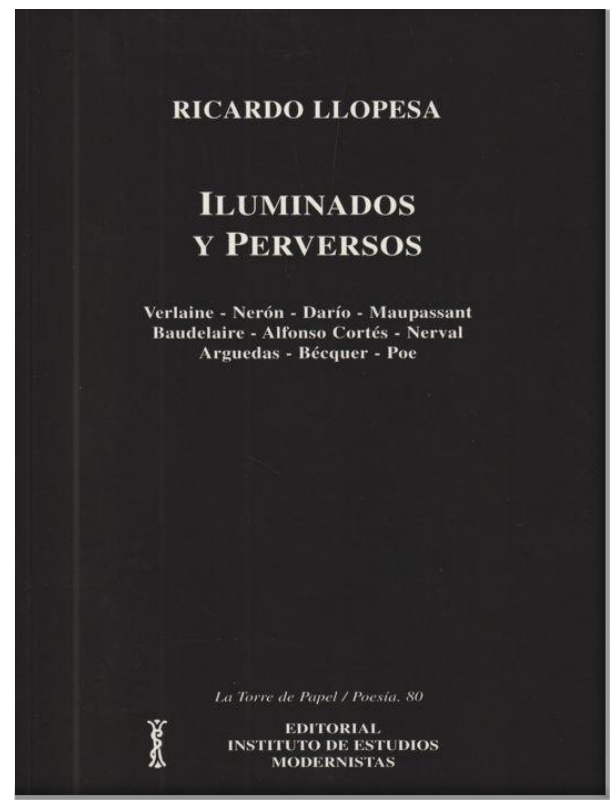

\section{LA BOTELLA (Ricardo Llopesa) (Fragmento)}

Vino quiero y vino pido. Tirso de Molina

Amo de ti tu cuello largo de garza, que mira el cielo con orgullo, y tu ancho cuerpo sin caderas. Amo tu espíritu, donde mis sueños reposan su blanda quietud nocturna.

En: Revista Letralia

Recuperado de 〈https://letralia.com/278/letras03.htm> 
Pero ante todo, Ricardo fue una gran persona que siempre estuvo dispuesto a prestar su ayuda y apoyo a todos aquellos jóvenes poetas que se cruzaron en su camino. En este contexto es en el que tuvieron lugar mis escasas, pero intensas vivencias con este enamorado del modernismo y de la ciudad donde echó raíces, Valencia.

Agonizaba el siglo XX cuando después de acabar mi segundo poemario "El sentido del navegante", me dispuse a la ardua labor de buscar una editorial que no tuviera reparos en publicar los poemas de un absoluto desconocido. Pasó un tiempo sin más noticias que las habituales negativas con las correspondientes y bienintencionadas disculpas, hasta que un día recibí una llamada desde Valencia. Me animó mucho que alguien que no conocía de nada y que dirigía una editorial "Instituto de Estudios Modernistas" me dijera cosas como que mis poemas estaban bien elaborados y se notaba la voz poética, una voz poética muy original; más o menos recuerdo sus palabras, aunque no me atrevo a entrecomillarlas dado el tiempo transcurrido: no es una poesía al uso y es sumamente refrescante, aunque algunos poemas, la mayoría no son fáciles y hay también que trabajarse la lectura. Como es natural caí en sus redes. Fui a Valencia a conocerlo aprovechando un viaje académico y me encontré un hombre extraordinariamente culto, amable y volcado en ayudarme con mi poemario; pero también a una persona que llevaba a cuestas una dolencia física que empezaba a manifestar sus síntomas. Una insuficiencia renal le iba a obligar a llevar un tratamiento que incidía plenamente en las limitaciones que se debía imponer en su estilo de vida. Me sorprendió que alguien en su situación tuviera el empuje, el humor y la simpatía tan a flor de piel. En el año 2000 vio la luz el poemario y Ricardo viajó hasta Alicante para presentarlo con la generosidad que le caracterizaba. El evento tuvo lugar en la desaparecida librería "Compas". A pesar de la escasez de público que confería un desangelado ambiente al evento, Ricardo, inmune al desaliento, lo dio todo. Era un orador brillante y lo de menos eran los poemas, lo auténticamente importante era escuchar las cosas que decía y cómo las decía. Luego cenamos juntos y mantuvimos una charla que aún mantengo fresca (o así creo, porque el presente del pasado casi nunca es totalmente fiel a la realidad pretérita), unas palabras en las que insistió en tres o cuatro aspectos que creo que han influido en mi obra posterior.

Una de las cuestiones que más me llamó la atención fue su idea sobre la falsa sencillez poética, esa poesía que busca la simplicidad a toda costa mediante el doble artificio: mutilar la realidad $y$ tomar sólo los pedacitos más light de la vida para hacer más entendible el poema. La belleza es compleja, tiene muchas caras, como la luna, y renunciar a la una es obviar a la otra. Un color es el resultado de la hermosa síntesis de una complejidad que participa de lleno en algo tan sublime como el azul. Ricardo apenas comía ni bebía, sólo charlaba y su capacidad de contención en este aspecto contrastaba con su vibrante oratoria.

Lo volví a a ver en un par de ocasiones en dos viajes que hizo a Alicante, pero de forma muy breve. Sí que mantuvimos un intercambio epistolar durante algún tiempo y se empeñó en proponer $\mathrm{mi}$ poemario al premio de la crítica valenciana. Posteriormente sólo charlamos por teléfono en un par de ocasiones. Creo que empleamos mal el tiempo porque siempre estamos atareados en cuarenta mil 
contingencias, mientras la vida pasa sin percatarnos lo que se nos escapa. Por eso lamento profundamente su muerte, pero también, egoístamente, no haber sido capaz de provocar más encuentros y charlas con este auténtico maestro del modernismo y amante del universo azul..., sí, Ricardo Llopesa fue muchas cosas. 